\title{
ANTHROPOLOGICAL STUDY OF SAMI FROM THE KOLA PENINSULA (RUSSIA)
}

\author{
Sergey Vasilyev ${ }^{1}$, Svetlana Borutskaya ${ }^{2}$ \\ ${ }^{1}$ Institute of Ethnology and Anthropology, \\ Russian Academy of Sciences (IEA RAS), Moscow, Russia \\ ${ }^{2}$ Moscow State University of M.V. Lomonosov (MSU), Moscow, Russia
}

\begin{abstract}
A study of the Sami burials on the territory of the Kolsky Bay was launched in 1976. All the material dates back to the $19^{\text {th }}-$ the beginning of the $20^{\text {th }}$ century. Collected skulls of 74 males and 51 females were compiled. We have investigated all the available material in the storage skulls. A homogeneity group analysis was conducted.

Sami males from the settlement of Yoakanga and Chalmnu-Varre vary by range of facial skeleton forming parameters. Sami females from the settlement Yoakanga and Chalmnu-Varre vary by facial skeleton widths. Based on the characters of lifetime body length and the proportion indexes of extremities, the Sami are the most adaptable to living conditions of the Far North.
\end{abstract}

Keywords: Angle morphometry; craniology; osteology; paleopathology; Sami; Kola Peninsula

\section{INTRODUCTION}

A study of the Sami burials on the territory of the Kolsky Bay was launched in 1976. In the course of expeditionary work obsequies were studied, cranial and osteological collections from the old Sami burials were compiled. During the first field season materials from the central part of the Kolsky Bay nearby village Chalmnu-Vare on the bank of the river Ponoya and from the coast of the Barents Sea from ex-burial close to the village Yoakanga were collected. In 1977 the Northern European paleoanthropological team of the Institute of Ethnography had continued works in the mouth of the river Yoakanga, increasing the 
amount of material from this point, and also there was a skull series acquired from the old burial in the mouth of the river Varzina (about $70 \mathrm{~km}$ to the west of Yoakanga). Beside this, not a large skull series was taken out from the west of the Kolsky Bay during excavations on the bank of Pulozero [19].

\section{MATERIALS AND METHODS}

All the material dates back to the $19^{\text {th }}$ - the beginning of the $20^{\text {th }}$ century. Collected skulls of 74 males and 51 females compiled a cranial collection registered at the Museum of Anthropology and Ethnography of the Russian Academy of Sciences (Kunstkamera).

We have investigated all the available skulls in the storage. A homogeneity group analysis was conducted.

The methods of angular skull morphometry that we have used in this work have grown up from the craniotrigonometrics research. The craniotrigonometric studies themselves originate from the $19^{\text {th }}$ century from Lissauer [25] and Topinard $[27,28]$ studies. These studies are being improved by the antropologists Klaatsch [22], Imbelloni [24] and Fritot [23] in the $20^{\text {th }}$ century and even programs of craniotrigonometric indications are made. The term "craniotrigonometry" had at one time been understood to mean studying of the sagittal skull projection with the help of angular sizes. Using the methods based on the sagittal skull projection in national science is connected with the names of Bunak [9], Gohman [11], Uryson [12,13], Benevolenskaya [14], Chistov [8], Pinchukova [17].

Except the developed programs of angular indications in the sagittal skull contour, successful efforts have been carried out to study angular sizes regardless of the sagittal plane by a number of researchers [10,21,26]. Mostly these studies were connected with the research of angular sizes of the skull face skeleton. As we have seen from experience, the essential role is not played by the general dimensions of the brain and the face skeleton, but sometimes the researchers' intuitive perception when the shape of separate skull parts, bone curvature, etc. are taken into account is important. Since the angle sizes for solving such tasks are more likely to be the most representative as they describe the skull shape, there is a need for creating a new program of skull angle morphometry, not necessarily connected with the sagittal plane. It would be more reasonable to divide such a program into two parts: the face skeleton and the braincase $[4,5]$. 
Measurement methods have been improving as new researches were made. At the beginning we have abandoned the sagittal conture assuming that such dots as nasion, bregma, lambda, opisthion, prosthion are not on the same plane even normally not to mention deformed posthumously and asymmetrical skulls. Then we have abandoned the sagittal plane that was used by Klaach and Fritot to estimate the skull shape in dimension.

To construct a triangle on paper, based on three measured skull chords and measure angles, using a protractor was relatively easy but not totally accurate. The program we have offered enables us to estimate dimensions, the level of curvature of any part of a braincase, in other words, to estimate the shape. That is why we call angle sizes forming dimensional characters. The last step in the development of the methodological guidelines was creating a computer program that calculates the angles based on the three chords using an openly accessible trigonometric cosinus theorem. Therefore, we have succeeded in the following: the angles measured by us are as credible as skull measurements. By joining the system of triangles, we have come up with a morphometric craniogram. Consequently, both digital and graphic material can be used for the comparative analysis.

We have drawn craniograms for the facial skeleton and the braincase of Sami from the Kola Peninsula under study. The drawing principal was the following: in order to use the standard metric scale, the value of the largest side in the triangular was taken for 100. It was the starting point of drawing the triangle using the calculated values of the angles; in order to avoid mistakes, the angles data were not rounded; the craniogram drawing was made in the plane, although having all the data it is possible to draw it in a space but it is more convenient to make a further combination and visual morphogram comparison in the plane state.

Only adult individuals' skeletal material was taken for paleo-osteological research. In general there were almost full skeletons in a relatively good state of preservation. In some cases restoring the original bone length was done by N.N. Mamonova [15]. Age and sex were determined by the known standard program $[7,16]$.

Detailed measuring and the descriptive analysis of skeletons has been conducted by us. The principal part of bone measurement has been done in accordance with the program set out in the work by V.P. Alekseev [1]. For the comparative analysis information about the outreach of indexes variety for the modern human being was taken from the works by Roginskij and by 
Hrisanfova $[18,20]$. Beside T. I. Alekseeva's data, the data about the body length of the modern Sami from the village Lovozero and the Tumen Nenets were used. Also, based on the data from this work some proportion indexes were calculated (the average values) [2]. The data on Eskimos extremities proportions from the Ipiutak burial, dated by the first half of the first millennium A. D, and the Eskimos data from the Tigara necropolis that lived in the beginning of the second millennium of A. D. were taken for this study [6]. The data on the Naukan Eskimos of the first half of the $20^{\text {th }}$ century were used in the comparison of the lifetime body length [3]. The data on the Karelians of the Lake Alozero Muezersk district in the Republic of Karelia is a result of our own research. Only average index values are provided, they are published for the first time. The Karelian graveyard dates back to the turn of the $17-18^{\text {th }}$ centuries.

\section{RESULTS AND DISCUSSION}

\section{Angle morphometry of Sami from the Kola Peninsula}

In general the series is comprised by quite gracile, with moderately evident brachycranic skull shapes with significant widths' and rather small heights' diameters. The values of naso-malar and zigo-maxillary angles indicate moderate facial flatness on both levels. Some skulls have little alveolar prognathism. A small protruding nose co-occurs with the high nasal bridge [19]. There have been two angle morphometry analyses of the male skull and two angle morphometry analyses of the female skull conducted by us. Only adult human skulls were used in the analysis.

\section{Angle morphometry of neurocranium}

In the first two there is an element describing 48 percent of variation, males are divided into two groups not connected with the location (Fig. 1). Mainly the groups are split based on the first component that describes the angle b-au-l and b-ast-l changes that indicates the curvature of bregma bone. Females are also split into two groups that are not connected with the location (Fig. 2). In contrast with males, they are determined by the second main component. Both components describe about 45 percent of variation. The second component shows b-n-ba, ba-n-pr, n-b-l angle changes. These angles show the difference in the braincase height, the base length of face and the vault of skull curvature. 


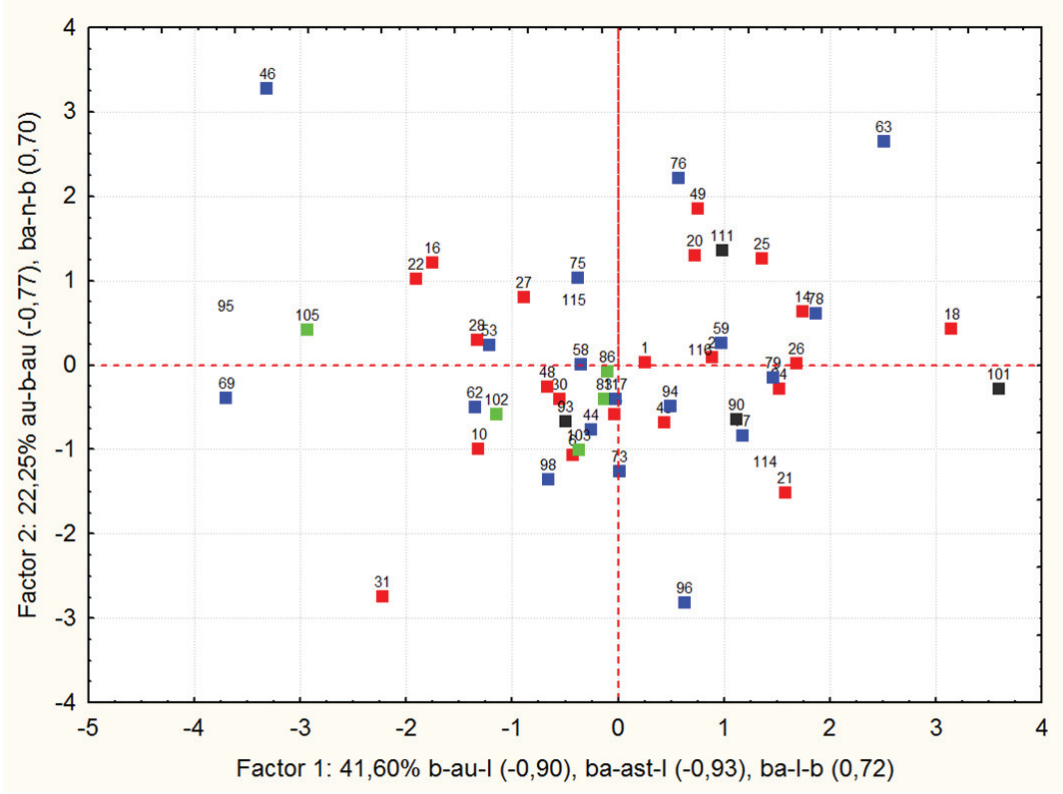

Red - Chalmnu-Vare, blue - Yoakanga, green - Pulozero, black - river Varzina.

Figure 1. Angle morphometry neurocranium. Male.

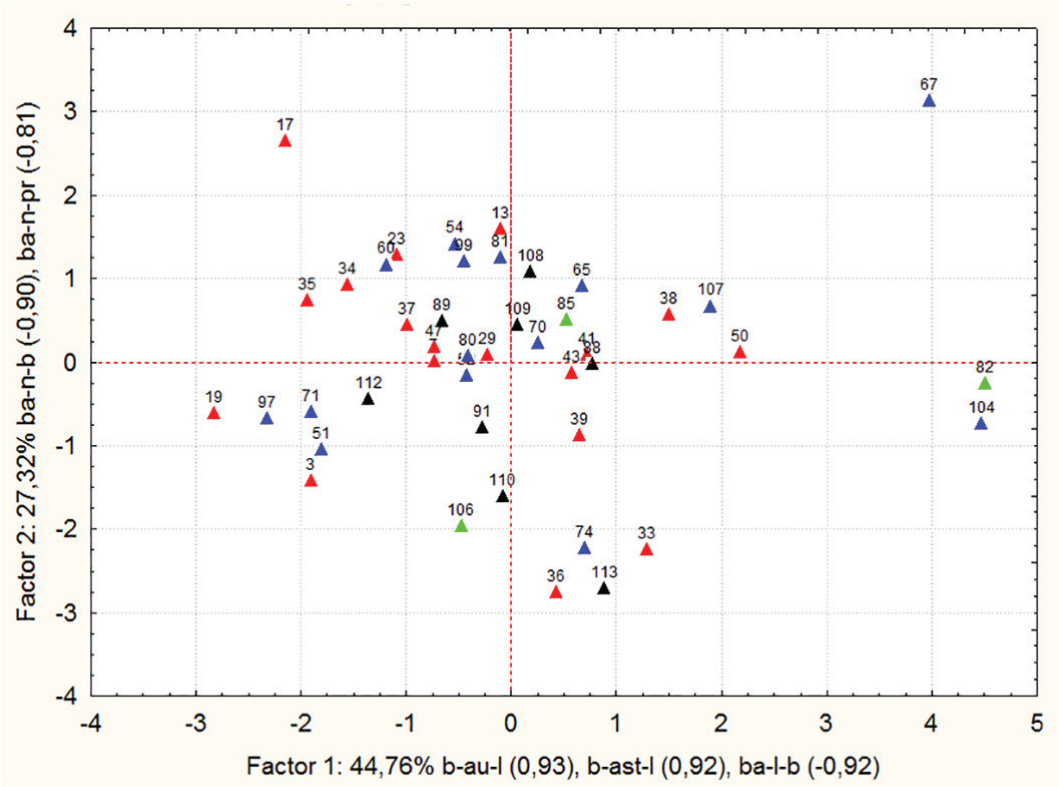

Red - Chalmnu-Vare, blue - Yoakanga, green - Pulozero, black - river Varzina.

Figure 2. Angle morphometry neurocranium. Female. 
Notably when the braincase height reduced, the base length of face is increasing and the curvature of skull dermal bones is weakened. As a rule these Sami angles have average values.

Therefore, it may be recognized that the Sami population of the Kolsky Bay is divided into two groups depending on the neurocranium shape. At the same time forming dimensional characters that are used to differentiate males and females are dissimilar.

\section{Angle morphometry of the facial skeleton}

The first two main components in the analysis of the male facial skeleton reflect more than 55 percent of variation (Fig. 3). Partition was based on the first component though it is not clear enough. Partition has placed them into the skulls from the village Yoakanga and the skulls from necropolis in the village Chalmnu-Varre. Forming the characters that have the main responsibility for the first component: zm-n-fmt, zm-nl-fmt, fmt-n-infor, zm-pr-infor. These angles on axe of $\mathrm{X}$ tend to increase. As a result of the conducted analysis we have found out that the men from Yoakanga are notable for the relatively higher cheek bone, the wider orbital cavity, the more massive zigo-maxillary zone than

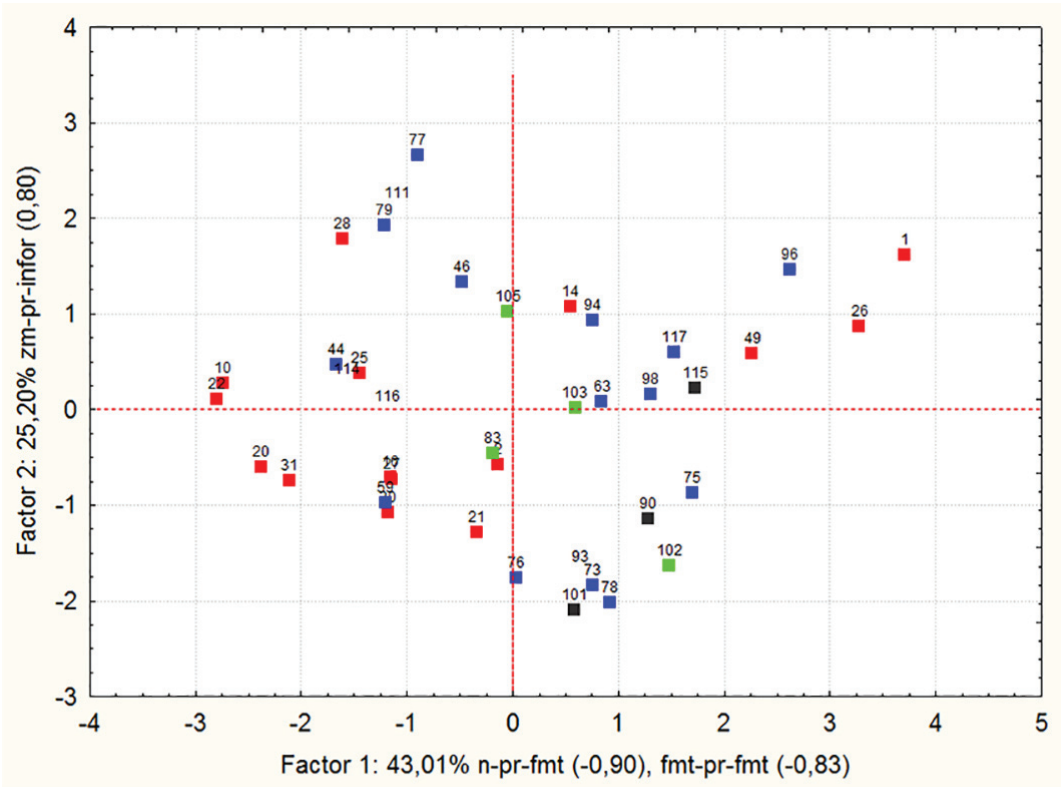

Red - Chalmnu-Vare, blue - Yoakanga, green - Pulozero, black - river Varzina.

Figure 3. Angle morphometry facial skeleton. Male. 


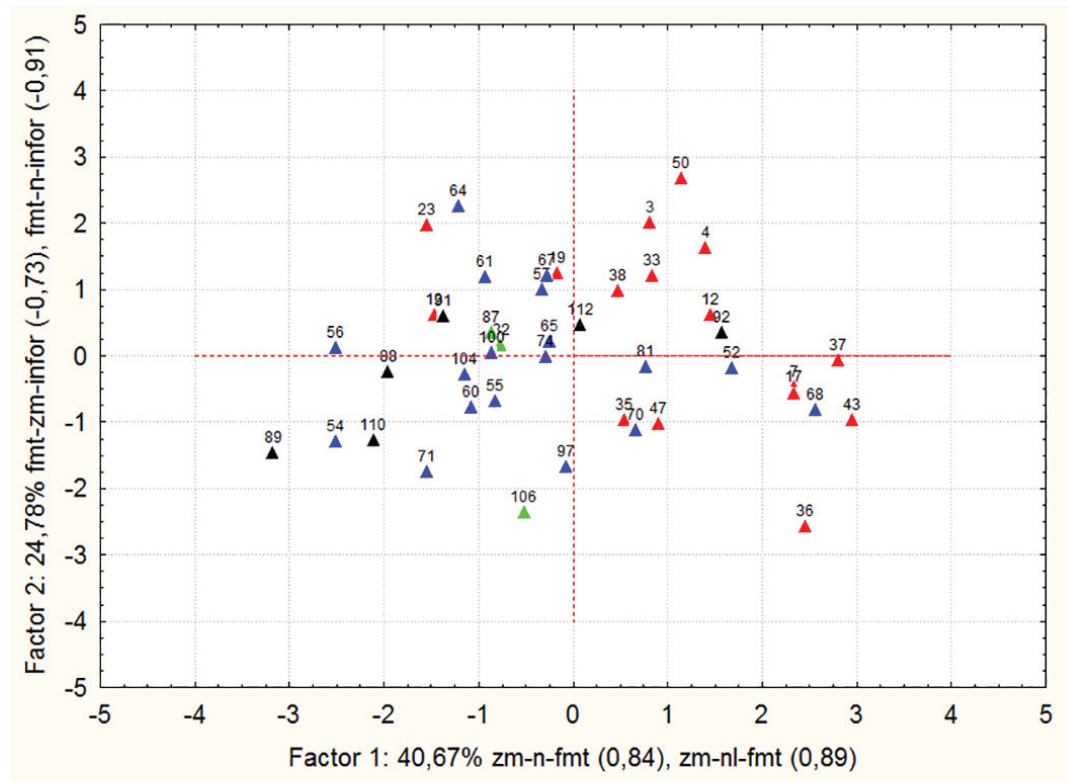

Red - Chalmnu-Vare, blue - Yoakanga, green - Pulozero, black - river Varzina.

Figure 4. Angle morphometry facial skeleton. Female.

the men from Chalmnu-Varre. Females also have two groups as a result of the analysis of the first two components that reflect around $60 \%$ of variation (Figure 4). They are also divided by the principle of belonging to a certain location. However, the characters used for the division are different: n-pr-fmt, fmt-pr-fmt, mt-infor-fmo. In other words, the females from Yoakanga had a slightly wider face in the upper part and respectively the wider orbital cavity than the females from Chalmnu-Varre.

\section{Osteological studies of Sami from the Kola Peninsula}

All the material taken for the research one way or another relates to the north, to the cold arctic and subarctic living conditions, the low insolation level. The groups of the Sami, the Eskimos and the Nenets have followed a certain historical path of forming morphological adaptation characters to respective life conditions.

Calculation results of the most significant, in our view, indexes are listed in Table 1 (for males) and 2 (for females). 
Table 1. Proportion indexes of male skeletons extremities of Sami and comparative groups

\begin{tabular}{llrrrrrr}
\hline Indexes & groups & $\mathbf{n}$ & $\mathbf{X}$ & $\min$ & $\max$ & $\boldsymbol{\sigma}$ & $\begin{array}{c}\text { Variability } \\
\text { for human } \\
\text { being }\end{array}$ \\
\hline Inter- & Sami & 12 & 72.67 & 70.04 & 77.47 & 1.26 & $60-84$ \\
membral & Karelians (Alozero) & 6 & 71.30 & & & & \\
& Eskimos (Ipiutak) & 43 & 71.00 & & & & \\
& Eskimos (Tigara) & 118 & 98.20 & & & & \\
\hline Radia- & Sami & 13 & 73.69 & 70.21 & 76.87 & 1.86 & $71-82$ \\
brahialis & Karelians (Alozero) & 6 & 74.05 & & & & \\
(brachial) & Eskimos (Ipiutak) & 43 & 74.80 & & & & \\
& Eskimos (Tigara) & 118 & 74.80 & & & & \\
\hline Tibia- & Sami & 13 & 77.92 & 73.12 & 81.69 & 1.74 & $77-87$ \\
femoris & Karelians (Alozero) & 8 & 77.79 & & & & \\
(crural) & Eskimos (Ipiutak) & 43 & 78.40 & & & & \\
& Eskimos (Tigara) & 118 & 81.10 & & & & \\
\hline Shoulder & Sami & 5 & $34.7 \mathrm{~cm}$ & $32.4 \mathrm{~cm}$ & $37.4 \mathrm{~cm}$ & 1.39 & \\
breadth & Karelians (Alozero) & 2 & $35.8 \mathrm{~cm}$ & & & & \\
\hline Width of & Sami & 7 & $25.6 \mathrm{~cm}$ & $24.8 \mathrm{~cm}$ & $27.2 \mathrm{~cm}$ & 2.49 & \\
pelvis & Karelians (Alozero) & 5 & $25.7 \mathrm{~cm}$ & & & & \\
\hline Pelvis & Sami & 7 & 84.1 & 80.15 & 87.89 & 0.69 & About 80 \\
index & Karelians (Alozero) & 5 & 86.07 & & & & \\
\hline & & & & & & & \\
\hline
\end{tabular}

The Sami of medium size have the intermembral index. In relation to this, groups are homogeneous. Average index values are similar to other groups. The Sami's radia-brahialis index is lower than the average that indicates a shortened brachium in relation to shoulder. The Sami brachium and the shoulder length ratio corresponds to one of these groups, adopted to cold conditions. The shorter the medial part of extremities (in this case of arm), the less evaporation, consequently less organism cooling. That is why it is quite logical that Sami and other northern peoples have a low value of the radia-brahialis index.

The Sami tibia-femoris index matches relatively shortened tibia in comparison with the thigh. Environmentally tibia as well as brachium, fulfills a "refrigerator" function. For this reason the shorter this structure, there is less organism cooling. 
Regarding the shoulder breadth, the Sami of the northern Kola Peninsula turned out to have too narrow shoulders. The Sami male width of pelvis is not large, sometimes it is average. With that according to the pelvis index, the pelvis itself can be described as really tall. Pelvis characteristics of Sami are similar to the same for Alozero Karelians.

According to the intermembral index (Table 2) northern Sami females differ by relatively shortened upper extremities. It is interesting to see how great is the difference based on the intermembral index between the Sami of the northern Kola Peninsula in the $19^{\text {th }}-20^{\text {th }}$ century and Lovozero Sami of the $20^{\text {th }}$ century.

The radia-brahialis index of Sami females showed that they are even more adaptive. From the values of tibia-femoris or the crural indicator one can conclude that the Sami females have too shortened tibia. Here we observe a clear sign of adaptation to life in the cold climate. Sami female shoulder breadths are too narrow. Their pelvis is narrow and shorter.

To calculate the lifetime body length of individuals we used Pearson and $\mathrm{Li}$, Bunak, De pertuis and Hedden formulas [1]. Results are listed in Tables 3 and 4.

Sami are characterized by average, lower than average and short lifetime body length. Upon that variability in the group is quite great. As an explanation one can consider metis presence in the group but it is impossible to check it.

Table 2. Proportion indexes of female skeletons

\begin{tabular}{lllllllc}
\hline Indexes & groups & $\mathbf{n}$ & $\mathbf{X}$ & $\min$ & $\max$ & $\boldsymbol{\sigma}$ & $\begin{array}{c}\text { Variability for } \\
\text { human being }\end{array}$ \\
\hline Intermembral & $\begin{array}{l}\text { Sami } \\
\text { Sami XX } \\
\text { century }\end{array}$ & 8 & $\begin{array}{l}73.06 \\
81.78\end{array}$ & 69.20 & 76.12 & 1.26 & $60-84$ \\
& & & & & & \\
\hline Radia-brahialis & Sami & 8 & 72.67 & 70.61 & 77.57 & 1.86 & $71-82$ \\
(brachial) & & & & & & & \\
\hline $\begin{array}{l}\text { Tibia-femoris } \\
\text { (crural) }\end{array}$ & Sami & 9 & 76.86 & 74.26 & 79.55 & 1.74 & $77-87$ \\
\hline Shoulder & Sami & 4 & $30.4 \mathrm{~cm}$ & $29.8 \mathrm{~cm}$ & $30.8 \mathrm{~cm}$ & 1.39 & \\
breadth & Sami XX & & $33.8 \mathrm{~cm}$ & & & & \\
& century. & & & & & & \\
\hline Width of pelvis & Sami & 3 & $25.9 \mathrm{~cm}$ & $25.2 \mathrm{~cm}$ & $26.4 \mathrm{~cm}$ & 2.49 & \\
& Sami XX & & $28.2 \mathrm{~cm}$ & & & & \\
& century. & & & & & & \\
\hline Pelvis index & Sami & 4 & 72.64 & 71.97 & 73.02 & 0.67 & about 76.5 \\
\hline
\end{tabular}


Table 3. Lifetime body length of males from groups under study and groups for comparison

\begin{tabular}{lccccc}
\hline Groups & $\mathbf{n}$ & $\mathbf{X}$ & $\min$ & $\max$ & $\boldsymbol{\sigma}$ \\
\hline Sami & 14 & $159.5 \mathrm{~cm}$ & $152.3 \mathrm{~cm}$ & $166.9 \mathrm{~cm}$ & 3.86 \\
Karelians & 9 & $164.8 \mathrm{~cm}$ & & & \\
Sami village Lovozero XX & 28 & $156.8 \mathrm{~cm}$ & & & \\
Tumen nenets XX & 34 & $159.9 \mathrm{~cm}$ & & & \\
Naukan eskimos beginning of XX & 20 & $162.7 \mathrm{~cm}$ & & & \\
\hline
\end{tabular}

Table 4. Lifetime body length of females Sami in comparison with other groups

\begin{tabular}{lccccc}
\hline Groups & $\mathbf{n}$ & $\mathbf{X}$ & $\min$ & $\max$ & $\boldsymbol{\sigma}$ \\
\hline Sami & 9 & $145.7 \mathrm{~cm}$ & $141.7 \mathrm{~cm}$ & $151.4 \mathrm{~cm}$ & 2.65 \\
Karelians & 2 & $154.3 \mathrm{~cm}$ & & & \\
Sami from village Lovozero & 18 & $147.1 \mathrm{~cm}$ & & & \\
Tumen nenets XX & 22 & $147.7 \mathrm{~cm}$ & & & \\
Naukan eskimos beginning of XX & 9 & $159.0 \mathrm{~cm}$ & & & \\
\hline
\end{tabular}

Opposed to Karelians and Naukan Eskimos all the females Sami and Nenets are characterized by a short stature. Probably there is a connection with the adaptation to cold.

Unfortunately, for the comparative analysis of the massiveness degree of long extremities bones we could provide only the material on medieval Karelians.

Kolsky Sami had average massive clavicles (or a bit more or less massive indicators than the modern human being). Humerus and cubits are gracile and medium-massive, redial bones are medium and high massive. Sami had various thighbones: from gracile to extremely massive. Karelians' leg bones in comparison with Samis' are the most gracile.

Sami females have a little more massive clavicles, humerus are gracile and mediu massive, redial bones are really massive, cubits are of different toughness. Massiveness of thighbones is various. Tibial bones are medium, massive or really massive. The most gracile tibial bones are observed in the Karelian group.

\section{Paleopathology research of Sami from the Kola Peninsula}

The next task of our work was to describe pathologic changes on skulls and postcranial skeleton bones and try to find the explanation for these pathologies taking into account the known climate living conditions of the groups under study. In the beginning a list of pathological changes on the skulls is presented as well as the percentage of occurrence in Sami group. 


\section{Skull pathologies}

1) Paradontosis - $77.5 \%$.

2) Hipoplasia of enamel - $36.9 \%$.

3) Caries $-32.4 \%$.

4) Lifetime loss of the most part of teeth and the reduction of alveolar arches $23.4 \%$.

5) Odontogene osteomyelitis - $18 \%$.

6) Dental calculus (ochreous light) $-12.6 \%$.

7) Crowding - $10.8 \%$.

8) Dome of cranium and facial skeleton osteoporosis (cribra) $51.4 \%$.

9) Cribra orbitalia $26.1 \%$.

10) Problems with the ear canal, inflammation of middle ear $24.3 \%$.

11) Arthrosis, maxillo-temporal joint arthritis $18.8 \%$.

12) Traumas, injuries $14.4 \%$.

Other pathologies: deflection of nasal septum, age diploe reduction, lateral abscess, odontogene periostitis, osteomas, etc.

Frequent occurrence of the dome of cranium and the facial bones porosis can be explained by a high bone vascularization, in such a way by heating certain head parts and eventually as an adaptation of the organism to cold windy climate conditions. Such pathologies as hypoplasia of enamel, paradontosis and Cribra orbitalia, we consider to be connected with a lack of vitamins in the food ration, a low insolation level and insufficient vitamin $\mathrm{D}$ production. The main Sami problem is infratemporal diseases. Occurrence percentage of caries, lifetime loss of the teeth with the reduction of alveolar arches afterwards, crowding, and dental calculus, odontogenic osteomyelitis. In the joint northern Sami group there are cases of odontogenic periostitis, maxillo-temporal joint diseases. Apparently, there is an influence of dietary habits.

\section{Postcranial skeletons pathologies}

1. Osteoporosis of long bones ends - almost all adult individuals have.

2. Periostitis, mainly of cnemis bones.

3. There are some other pathologies: osteoarthrosis of the knee, elbow joint arthrosis, elbow joint trauma and other isolated cases.

From the list of pathological bones changes of postcranial skeleton it is seen that the main Sami pathologies were osteoporosis (mainly the ends of the long 
bones) and leg bones periostitis, mainly of cnemis, often with signs of bruises. The presence of osteoporosis in groups is likely to be connected with a lack of vitamins in the dietry intake, insufficient vitamin $\mathrm{D}$ production, probable hormone disruption, and may be with the lack of calcium in food and water.

Sami, fishermen, reindeer herders could have lots of traumatic situations and moments when they had to be in cold conditions that could lead to disease development which includes periostitis.

\section{CONCLUSIONS}

1. Sami males in the $19^{\text {th }}$ - beginning of the $20^{\text {th }}$ centuries from the settlements of Yoakanga and Chalmnu-Varre vary by range of facial skeleton forming parameters. These are cheek bone height, orbital cavity width and zigomaxillary zone robusticity. Diversity in the shapes of neurocranium is not connected with location.

2. Sami female in the $19^{\text {th }}$ - the beginning of $20^{\text {th }}$ centuries from the settlements Yoakanga and Chalmnu-Varre vary by facial skeleton widths. Diversity in the shapes of neurocranium is also not connected with location.

3. Based on the characters of lifetime body length and proportion indexes of extremities the Sami are the most adaptable to living conditions of the Far North. Sami postcranium skeleton, at least extrimities skeleton was a little more massive than Karelians'.

4. Typical Sami skeleton pathologies were the dome of cranium and facial skeleton porosis, parodontitis, hypoplasia of enamel, postcranium skeleton bones porosis, signs of bruises and periostitis on leg bones, mainly on cnemis. Sami of the northern Kolsky Bay quite often have dentofacial pathologies.

5. One third of the Sami individuals had caries. This distinction is connected with the genetic characteristics of the groups, the time of their existence, the diet type and some other reasons.

\section{REFERENCES}

1. Alekseev V.P. (1966). Osteometriya. Moscow: Nauka, 251.

2. Alekseeva T.I. (1977). Geograficheskaya sreda i biologiya cheloveka. Moscow: Mysl', 302. 
3. Alekseeva T.I., Kovalenko V.Yu. (1980). Morfofunktsional'nye harakteristiki postkranial'nogo skeleta aziatskih eskimosov. Antropologiya Sibiri, Moscow, 131-153.

4. Vasilyev S.V. (1996). Trigonometriya litsevogo skeleta iskopaemyh gominid. Vestnik antropologii, 2, 227-245.

5. Vasilyev S.V. (1997). Trigonometriya mozgovoj korobki iskopaemyh gominid. In: Novye metody - novye podhody v sovremennoj antropologii, Moscow, 68-81.

6. Debets G.F. (1986). Paleoantropologiya drevnih eskimosov (Ipiutak, Tigara). Etnicheskie svyazi narodov severa Azii i Ameriki po dannym antropologii. Moscow.

7. Dobryak V.I. (1968). Vozrastnye osobennosti simfiza lobkovyh kostej. Voprosy antropologii, 29, 140-146.

8. Chistov Yu.K. (1980). Voprosy izmenchivosti medianno-sagittal'nogo kontura cherepa cheloveka v protsesse antropogeneza. Sovremennye problemy i novye metody $\mathrm{v}$ antropologii. Leningrad: Nauka, 139-162.

9. Bunak V.V. (1959). Cherep cheloveka i stadii ego formirovaniya u iskopaemyh lyudej i sovremennyh ras. Trudy Instituta etnografii AN SSSR, 59, 284.

10. Bunak V.V. (1960). Licevoj skelet i faktory, opredelyayuschie variatsii ego stroeniya. Trudy Instituta etnografii AN SSSR, 60, 84-152.

11. Gohman I.I. (1962). Novaya metodika vychisleniya srednih konturov kraniologicheskih serij. Sovetskaya Etnografiya, 2, 125-130.

12. Uryson M.I. (1970). Sootnositel'naya izmenchivost' komponentov sagittal'nogo svoda cherepa u sovremennogo i iskopaemogo cheloveka. Voprosy antropologii, $34,76-85$.

13. Uryson M.I. (1972). Izmenchivost' i proportsii komponentov sagittal'nogo svoda cherepa u sovremennogo i iskopaemogo cheloveka. In: Novejshaya tektonika, novejshie otlozheniya i chelovek. T. 3. Moscow: Nauka, 187-199.

14. Benevolenskaya Yu.D. (1976). Problemy etnicheskoj kraniologii. Leningrad: Nauka, 156.

15. Mamonova N.N. (1968). Opredelenie dliny kostej po ih fragmentam. Voprosy antropologii, 29, 171-177.

16. Pashkova V.I. (1963). Ocherki sudebno-meditsinskoj osteologii. Moscow: Medgiz, 66-71.

17. Pinchukova I.M. (1982). Opyt issledovaniya kraniologicheskih serij metodom kraniotrigonometrii. Voprosy antropologii, 70, 108-120.

18. Roginskij Ya.Ya., Levin M.G. (1978). Antropologiya. Moscow: Vysshaya shkola, 528.

19. Hartanovich V.I. (1980). Novye materialy k kraniologii saamov Kol'skogo poluostrova. Issledovaniya po paleoantropologii i kraniologii SSSR. XXXVI, 35-47.

20. Hrisanfova E.N. (1978). Evolyutsionnaya morfologiya skeleta cheloveka. Moscow: MGU, 216. 
21. Aiello L., Dean C. (1990). Human evolutionary anatomy. London, 608.

22. Klaatsch H. (1909). Kraniomorphologie und Kraniotrigonometrie. Arch Anthropol, N.F., 8, 34-49.

23. Fritot H. R. (1964). Craneotrigonometria. La Habana, 198.

24. Imbelloni J. (1921). Introducción a Nuevos Estudios de Cráneotrigonometria. Anales del Museo Nacional de Historia Natural de Buenos Aires, XXXI, 31-94.

25. Lissauer A. (1885). Untersuchungen über die sagittale Krummung des Ichades bei den Anthropoiden und den verschiedenen Menschenrassen. Arch Anthropol, 15, 9-120.

26. Pope G.G. (1991). Evolution of the zygomaticomaxillary region in the genus Homo and its relevance to the origin of modern humans. J Human Evolution, 21, 189-213.

27. Topinard P. (1885). Eléments d’anthropologie générale. Paris, 234.

28. Topinard P. (1894). Anthropologia. Historia Natural. Barcelona, 1, 208-225.

\section{Address for correspondence:}

Sergey Vasilyev

Institute of Ethnology and Anthropology

Russian Academy of Sciences (IEA RAS), Moscow

Leninskij prospekt 32A, 119334, Moscow, Russia

E-mail: vasbor1@yandex.ru 